\title{
THE SEVENTH EU ENLARGEMENT AND BEYOND: PRE-ACCESSION POLICY VIS-À-VIS THE WESTERN BALKANS REVISITED
}

\author{
Mirna Vlašić Feketija and Adam Łazowski
}

Summary: The accession of Croatia to the European Union is yet another milestone in the history of EU enlargements. After seven enlargement rounds the membership has increased from the original six founding countries to twenty-eight Member States. Many claim, quite rightly, that the enlargement policy is the most successful of the EU's foreign policy tools. Even those who bring this bold argument into doubt have to agree that, when contrasted with other external policies, and the European Neighbourhood Policy in particular, the overall balance sheet of the enlargement policy is positive. The accession of Croatia is symbolic in a number of ways. As argued in this article, it closes one big chapter in the history of EU enlargements but, at the same time, opens another. Croatia is - most likely - the last country to join the EU this decade. After a sometimes painful pre-accession process, it has proved to be a 'success story' of the stabilisation and association process. As the European Commission claims, it is living proof that the raison d'être and mechanics of the policy employed vis-à-vis the Western Balkans have their merits. However, a quick look into the future proves that the next enlargements will be far more complicated affairs. The current list of candidates and potential candidates is a mix of a heavyweight (Turkey) and the Western Balkan countries, all struggling to meet the fundamental prerequisites for a democracy based on the rule of law. Failure to comply with the Copenhagen criteria, together with a dwindling appetite for further enlargement among some Member States, create a rather dangerous mix. This article argues that following recent enhancements to the pre-accession policy, further improvements are necessary to make future expansions of the European Union possible. If only from the geo-political perspective, this is in the joint interest of the European Union, its Member States and the countries of the Western Balkans.

\footnotetext{
Mirna Vlašić Feketija, Advisor to the Minister of Foreign and European Affairs of Croatia; Dr Adam Lazowski, Professor of European Union Law at the Westminster Law School, University of Westminster, London. This article presents strictly the personal opinions of the authors.
} 
Mirna Vlašić Feketija, Adam Łazowski: The Seventh EU Enlargement and...

\section{Introduction}

The EU enlargement policy is often considered as the most successful EU external policy. ${ }^{1}$ Despite all its flaws it has undoubtedly evolved into a catalyst of democratisation and comprehensive reforms in Central and Eastern Europe. ${ }^{2}$ With the successful completion of Croatia's rapprochement, the enlargement policy also vindicated the stabilisation and association process in the Western Balkans. ${ }^{3}$ Indeed, Croatia is the first of the countries established on the ashes of Yugoslavia to go through a full cycle: from the establishment of formal relations with the EU, through negotiations of the Stabilisation and Association Agreement ${ }^{4}$ followed by its implementation, through accession negotiations to a successful ratification and entry into force of the Accession Treaty. ${ }^{5}$ It is now a point of reference for the remaining ex-Yugoslav countries that aspire to member-

1 For instance, the European Commission in 2008 stated: 'Enlargement is one of the EU's most powerful policy tools. It serves the EU's strategic interests in stability, security, and conflict prevention. It has helped to increase prosperity and growth opportunities, to improve links with vital transport and energy routes, and to increase the EU's weight in the world'. See further Communication from the Commission to the Council and the European Parliament, 'Enlargement strategy and main challenges 2008-2009' COM (2008) 674 final, 2.

2 From the vast literature on EU enlargement, see inter alia, A Mayhew, Recreating Europe. The European Union's Policy towards Central and Eastern Europe (CUP 1999); A Ott and K Inglis (eds), Handbook on European Enlargement. A Commentary on the Enlargement Process (TMC Asser Press 2002); M Cremona (ed), The Enlargement of the European Union (OUP 2003); C Hillion (ed), EU Enlargement. A Legal Approach (Hart Publishing 2004); W Jacoby, The Enlargement of the European Union and NATO. Ordering from the Menu in Central and Eastern Europe (CUP 2004); N Nugent (ed), European Union Enlargement (Palgrave Macmillan 2004); AL Dimitrova (ed), Driven to Change: The European Union's Enlargement Viewed from the East (Manchester University Press 2004); E Brimmer and S Fröhlich (eds), The Strategic Implications of European Union Enlargement (Center for Transatlantic Relations 2005); AF Tatham, Enlargement of the European Union (Wolters Kluwer 2009).

3 The European Commission claims that: ' $[\mathrm{t}] \mathrm{he}$ completion of accession negotiations with Croatia, opening the way to membership in mid-2013, vindicates the policy adopted in the aftermath of the devastating Balkan conflicts of the 1990s [...] it is [a] fresh evidence for the transformational power of the EU's enlargement policy [...]'. See further: Commission, 'Enlargement Strategy and Main Challenges 2011-2012' (Communication) COM (2011) 666 final, 2.

4 Stabilisation and Association Agreement between the European Communities and their Member States, of the one part, and the Republic of Croatia, of the other part [2005] OJ L26/3.

5 Treaty between the Kingdom of Belgium, the Republic of Bulgaria, the Czech Republic, the Kingdom of Denmark, the Federal Republic of Germany, the Republic of Estonia, Ireland, the Hellenic Republic, the Kingdom of Spain, the French Republic, the Italian Republic, the Republic of Cyprus, the Republic of Latvia, the Republic of Lithuania, the Grand Duchy of Luxembourg, the Republic of Hungary, the Republic of Malta, the Kingdom of the Netherlands, the Republic of Austria, the Republic of Poland, the Portuguese Republic, Romania, the Republic of Slovenia, the Slovak Republic, the Republic of Finland, the Kingdom of Sweden, the United Kingdom of Great Britain and Northern Ireland (Member States of the European Union) and the Republic of Croatia concerning the accession of the Republic of Croatia to the European Union [2012] OJ L112/10. For an academic appraisal, see A Łazowski, EU Do Not Worry, Croatia Is Behind You: A Commentary on the Seventh Accession Treaty (2012) 8 Croatian Yearbook of European Law \& Policy 1. 
ship, as well as for neighbouring Albania. One may, of course, compile a list of accession policy failures and drawbacks combined with a catalogue of failed deliverables. ${ }^{6}$ Nevertheless, the overall balance sheet is arguably positive. With the accession of Croatia, the pre-accession policy closed one of its most important chapters and opened another. Croatia is, most likely, the last country to join in this decade. Compared to the other countries in the queue, it is the most politically and economically advanced and, in many ways, is closer to the previous enlargement rounds than what the future enlargements will amount to. As acknowledged by the European Commission in the most recent progress report, the current candidate and potential candidate countries are suffering from rather profound challenges of statehood. This requires increased attention, assistance, including an even more tailor-made pre-accession policy. ${ }^{7}$ As much as it has changed after the previous two rounds of enlargement, it still needs further enhancements, taking into account the idiosyncrasies of the current candidate and potential candidate countries. ${ }^{8}$ An enhanced negotiation strategy, putting Chapters 23 and 24 at the centre of gravity, is an important step forward. However, with similar commitment, the European Union needs to tackle other aspects of the pre-accession effort, particularly law approximation, more targeted and streamlined use of IPA funding, as well as the very mundane and resource-thirsty translation of the EU acquis. The bottom line is that the current pre-accession policy is a peace-building and peacekeeping endeavour par excellence, as well as a state-creation exercise that will take years to accomplish. On the one hand, it will take the current candidate and potential candidate countries years to meet all the opening, interim and closing benchmarks which have now become an inherent part of the accession negotiations. On the other hand, the prospect of EU accession is an important catalyst that mightily contributes to (relatively) peaceful regional relations and facilitates peace building in a region that was in flames until the beginning of the 21 st century. One cannot forget, however, that being a catalyst, the pre-accession policy is not a magic wand. Without solid external support combined with a favourable domestic political climate there is a risk that the non-EU Western Balkan countries will drift into malaise. In this article, we argue that, as things stood at the end of 2014, the European Union was in great need of striking a fine balance between pursuing a

6 For a critical appraisal, see D Kochenov, EU Enlargement and the Failure of Conditionality. Pre-accession Conditionality in the Fields of Democracy and the Rule of Law (Wolters Kluwer 2008).

7 Communication from the Commission to the European Parliament, the Council, the European Economic and Social Committee and the Committee of the Regions, 'Enlargement Strategy and Main Challenges 2014-15' COM (2014) 700 final.

8 As this article went to print, the candidate countries included Turkey, Montenegro, Serbia, Albania, the Former Yugoslav Republic of Macedonia, while Bosnia and Herzegovina as well as Kosovo had the status of potential candidates. 
robust and merit-based pre-accession policy and maintaining the momentum of the process. The stakes are simply too high not to. From the geo-political perspective, all this is in the joint interest of the European Union, its Member States and the countries of the Western Balkans. The appointment of the new European Commission is a good opportunity, which, however, may be easily missed. The reduction of the portfolio of Commissioner Hahn to the accession negotiations sends a very bad signal at many levels. It is as bad as the bold statement of the new President of the European Commission who openly argued that there would be no further enlargement of the EU in the next five years. Although this, in all likelihood, is true, it may be perceived by the current candidate and potential candidate countries as a message of the EU's dwindling passion for enlargement. ${ }^{9}$ Arguably, this is the last thing that the EU's pre-accession policy needs now. In this article, we argue that this is the wrong way forward. What is needed instead is a further strengthening of the policy currently employed vis-à-vis the Western Balkans. ${ }^{10}$

The analysis that follows is structured in the following way. The point of departure is Croatia's experience of accession to the European Union (section 2). This will form a solid foundation for section 3 devoted to a revamped pre-accession policy currently employed vis-à-vis Montenegro and Serbia. A set of recommendations for further improvements of the enlargement policy is provided in the closing section of this article.

\section{Towards an enhanced pre-accession policy: the Croatian experience}

\subsection{Introduction}

The accession negotiations were officially closed on 31 June 2011. On that day, all who were deeply involved in this endeavour could sigh in relief - the process that had lasted almost a decade was coming to a fruitful end and the historic goal of EU membership was on the horizon. In the first two decades of its existence as a sovereign country, Croatia has gone a long way from the declaration of independence and the war trauma, through association with the European Union to membership. At that point, the only hurdles on the way to accession were the signature and the ratification of the Accession Treaty. The journey indeed marked a big leap forward, although one should emphasise that it was not even remotely easy to accomplish. It took years to complete and required great

\footnotetext{
9 Similar criticism in E Fouéré, 'The EU's Enlargement Agenda: Credibility at Stake?' (31 October 2014) CEPS Policy Brief, No 324.

10 For more on the current policy, see, inter alia, MA Vachudova, 'EU Leverage and National Interests in the Balkans: The Puzzles of Enlargement Ten Years On' (2014) 52 Journal of Common Market Studies 122.
} 
determination of those involved. It should be added that it was the first accession based on enhanced modus operandi redeveloped to counterbalance the unsatisfactory experience with the sixth enlargement and to reflect the somewhat reduced appetite among some EU Member States to proceed with further expansions of the club. As far as the latter is concerned, quite inevitably, the absorption capacity discourse came back to the fore. ${ }^{11}$ Against this EU internal background, the tailor-made preaccession policy applied to Croatia was developed. It had to be based on the previous modus operandi but subject to a number of enhancements resulting from Croatia's legacy as a post-Yugoslav state that, not long before the start of accession negotiations, had been involved in the Balkan War. These three factors, among others, played a crucial role in Croatia's accession to the European Union and they are analysed in turn. ${ }^{12}$

\subsubsection{The sixth enlargement and beyond}

The accession of Bulgaria and Romania in 2007 was, according to many, not the finest hour of the EU enlargement policy. Both new entrants were not ready for membership and suffered from considerable problems with the rule of law affecting a variety of state institutions, including the law enforcement authorities. ${ }^{13}$ This experience uncovered a number of weaknesses of the then pre-accession policy, but also the naiveté of political circles that believed in the magic transformative power that EU membership would have. It also encapsulated a profound weakness in the EU's law enforcement architecture, whereby the standard procedural mechanisms - the infraction proceedings - are of little use in the case of rule of law breaches, ${ }^{14}$ and Article 7 TEU is too fortified with the Member States' involvement to serve any purpose. ${ }^{15}$ Stuck between a rock and a hard place, the EU Members States concluded the accession negotiations, yet included in the Accession Treaty a membership postponement clause. ${ }^{16}$ This was nothing more than a symbolic gesture,

\footnotetext{
11 See further section 2.1.2 below.

12 For an academic appraisal of Croatia's accession process see, inter alia, T Cerruti, 'The Political Criteria for Accession to the EU in the Experience of Croatia' (2014) 20 European Public Law 771.

13 See, inter alia, Kochenov (n 6).

14 For the European Commission to proceed with infringement proceedings based on Articles 258/260 TFEU, the alleged breach has to have a proper anchor in EU law. To put it differently, a Member State must be in breach of a particular provision of the Founding Treaties or secondary legislation. Furthermore, due to a caveat laid down in Article 51 of the Charter of Fundamental Rights, it is not possible to solely employ the Charter in infringement proceedings. See further A Łazowski, 'Decoding a Legal Enigma: The Charter of Fundamental Rights of the European Union and Infringement Proceedings' (2013) 14 ERA Forum 573.

15 See, inter alia, W Sadurski, 'Adding Bite to a Bark: The Story of Article 7, EU Enlargement, and Jörg Haider' (2010) 16 Columbia Journal of European Law 385.

16 Treaty between the Kingdom of Belgium, the Czech Republic, the Kingdom of Denmark,
} 
as the postponement was available for one year only. With the scale of challenges ahead of both acceding countries, it was rather naïve to assume that a single year could trigger such a tectonic change. So, on the one hand, a decision was made to let both countries in, as planned on 1 January 2007, and, on the other hand, to continue with scrutiny of the newcomers' performance. The European Commission designed a Co-operation and Verification Mechanism that was meant to serve as an extended arm of the pre-accession policy once membership turned into reality. ${ }^{17}$ Eight years after the sixth enlargement of the European Union, this mechanism is still in place, which encapsulates its weaknesses and the scale of the unpreparedness of the two countries that celebrated accession on 1 January 2007. It is enough to take a glimpse of the most recent six-monthly CVM reports to prove this point. For instance, in the Report on Bulgaria published in January 2014, on top of Government changes that had occurred three times in 18 months (raising concerns about the lack of leadership in reforms), the European Commission again emphasised the necessity for transparency and integrity in promotions in the judiciary, the challenges of case allocation, improvement in the prosecution set-up, the implementation of court decisions, as well as ensuring one-spot coordination of the fight against corruption. ${ }^{18}$ All these were also sources of concern in the case of Croatia, so they were incorporated into the benchmarks for Chapters 23 and $24 .{ }^{19}$

the Federal Republic of Germany, the Republic of Estonia, the Hellenic Republic, the Kingdom of Spain, the French Republic, Ireland, the Italian Republic, the Republic of Cyprus, the Republic of Latvia, the Republic of Lithuania, the Grand Duchy of Luxembourg, the Republic of Hungary, the Republic of Malta, the Kingdom of the Netherlands, the Republic of Austria, the Republic of Poland, the Portuguese Republic, the Republic of Slovenia, the Slovak Republic, the Republic of Finland, the Kingdom of Sweden, the United Kingdom of Great Britain and Northern Ireland (Member States of the European Union) and the Republic of Bulgaria and Romania, concerning the accession of the Republic of Bulgaria and Romania to the European Union [2005] OJ L157/11. For a legal appraisal see, inter alia, A Łazowski, 'And Then They Were Twenty-Seven... A Legal Appraisal of the Sixth Accession Treaty' (2007) 44 CML Rev 401.

17 Commission Decision 2006/928/EC of 13 December 2006 establishing a mechanism for co-operation and verification of progress in Romania to address specific benchmarks in the areas of judicial reform and the fight against corruption [2006] OJ L354/56; Commission Decision 2006/929/EC of 13 December 2006 establishing a mechanism for cooperation and verification of progress in Bulgaria to address specific benchmarks in the areas of judicial reform and the fight against corruption and organized crime [2006] OJ L354/58. For an academic appraisal see, inter alia, M Spernbauer, 'Benchmarking, Safeguard Clauses and Verification Mechanism - What's in a Name? Recent Developments in Pre-and Post-accession Conditionality and Compliance with EU Law' (2007) 3 Croatian Yearbook of European Law and Policy 273

18 Commission, Report to the European Parliament and the Council 'On Progress in Bulgaria under the Co-operation and Verification Mechanism' (Communication) COM (2014) 36 final.

19 See further section 2.2 of this article. 


\subsubsection{Absorption capacity of the European Union}

The big bang enlargement of the European Union, followed shortly by the accession of Romania and Bulgaria, reignited a contentious debate about the EU's absorption capacity. ${ }^{20}$ This is understood by the European Commission as the 'capacity of the Union to maintain the momentum of European integration as it enlarges [and it] has three main components: institutions, common policies, and budget'. ${ }^{21}$ Furthermore, as the Commission explains, in order to remain a functioning entity, the Union needs to ensure that its institutions continue to act effectively, that its policies meet their goals, and that its budget is commensurate with its objectives and with its financial resources. Arguably, the absorption capacity includes also the effective application of EU law at the national level and special attention should be paid to it, both in the existing and future Member States. Political discourse often lacks understanding that the EU is not one of many international organisations of an intergovernmental character, but a supranational entity underpinned by a specific legal order. It is the efficacy of this legal system, coupled with the capacity to function effectively in the decision-making sphere, that should determine the EU's integration capacity. The latter clearly has its limits.

It should be noted, however, that this discourse is nihil novi as its origins can be traced back to the early enlargements of the then European Communities. The problem of indispensable institutional reforms (making it possible to enlarge the membership from six to nine states) was already raised at the beginning of the 1970s in the context of the EEC accession of the UK, Ireland and Denmark. Analogous arguments were advanced along with the successive enlargements of the European Communities/European Union and paradoxically they remain valid to this day. Such views resulted from a conviction that the institutional system created for the six founding member states is devoid of the capacity to function further in enlarged membership. ${ }^{22}$

\footnotetext{
20 See further, inter alia, A Łazowski, 'Treaty of Lisbon and the EU's Absorption Capacity' (2010) 19 The Polish Quarterly of International Affairs 56.

${ }^{21}$ Communication from the European Commission to the European Parliament and the Council. 'Enlargement Strategy and Main Challenges 2006 - 2007 Including annexed special report on the EU's capacity to integrate new members' COM (2006) 649 final.

22 For instance, in 1978 the European Commission argued: 'The institutions and organs of the present Community cannot ensure that the progress of integration will continue in an enlarged Community: on the contrary, there is a reason to fear that the Community decision making procedures will deteriorate. If this happened, it would be difficult or even impossible to create a Community based on the rule of law, which is the foundation of the Community and the sole means of recognizing in law that to equal rights correspond equal obligations. The institutions and organs of the enlarged Community must accordingly be decisively strengthened'. See Communication sent by the Commission to the Council on 20 April 1978, 'General considerations on the problems of enlargement' COM (78) 120 final, 15.
} 
In the Copenhagen Conclusions of the European Council, the capacity to include more countries in the European Union became a formal fourth enlargement criterion. ${ }^{23}$ With a near doubling of the Member States it was inevitable that the absorption capacity discourse would gain strength. Whether rightly so or not, it was also used as an argument to push constitutional reform and, after the demise of the Treaty establishing a Constitution for Europe, it served as the raison d'etre for institutional changes provided for in the Treaty of Lisbon. ${ }^{24}$ It is striking that the first version of the Preamble to the Reform Treaty (later rebranded as the Treaty of Lisbon) contained the following statement: 'Desiring to complete the process started by the Treaty of Amsterdam and by the Treaty of Nice of adapting the institutions of the European Union to function in an enlarged Union'. ${ }^{25}$ This, of course, was later dropped and replaced with a vaguer and less self-incriminating clause.

The debate in question, although potentially very powerful, did not stop the European Union from offering membership of the European Union to the Western Balkan countries. In 2006, the European Council repeated its commitment to enlargement, although it made the decisionmakers more aware that the political aspects of enlargement should not prevail over robust scrutiny of the aspiring countries, as admitting states that do not meet the Copenhagen criteria may ultimately weaken the European Union and undermine its capacity to react effectively to the challenges ahead. At the same time, the European Commission, entertained a request of the European Council and presented a Report on the Absorption Capacity. ${ }^{26}$

\subsubsection{Geography defines you}

In the early stages of its rapprochement, Croatia turned to its neighbours, also post-communist countries and ex-Soviet republics, to gain from their pre-accession experience. The Croatian authorities considered and analysed how the process was managed in the countries that were similar in size, administrative setting/culture, political system and/or national interest. As things moved forward, it became rather clear that it

${ }^{23}$ Conclusions of the European Council at Copenhagen, 21-22 June 1993, Bull EU 6-1993, point 13.

24 Treaty of Lisbon amending the Treaty on European Union and the Treaty establishing the European Community, signed at Lisbon, 13 December 2007, OJ C306/1. For an academic appraisal see, inter alia, J-C Piris, The Lisbon Treaty. A Legal and Political Analysis (CUP 2010); P Craig, The Lisbon Treaty: Law, Politics, and Treaty Reform (OUP 2010); A Biondi, P Eeckhout and S Ripley (eds), EU Law after Lisbon (OUP 2012); M Trybus and L Rubini (eds), The Treaty of Lisbon and the Future of European Law and Policy (Edward Elgar Publishing 2012).

25 Draft Treaty amending the Treaty on European Union and the Treaty establishing the European Community. Draft Preamble, Brussels 24 July 2007, CIG 4/07.

26 Commission (n 21). 
was all very useful but only to a certain degree. The idiosyncrasies of the Croatian path towards the EU were coming to the surface, with conditions and starting points different, or to put it differently, tailor-made. At the same time, the 2004 and 2007 rounds of accessions sent an important signal to Croatia; it was an additional motivation to double the efforts in order to catch up, at least partially. As the late Nelson Mandela used to say 'it always seems impossible until it's done'. So, a good example demonstrating that membership was possible, was - no doubt - a catalyst. A brief reminder is fitting that all Central and Eastern European Countries had to comply with the Copenhagen criteria ${ }^{27}$ and were subjected to a specifically designed pre-accession policy that had never been applied prior to the Western European countries during their rapprochement. ${ }^{28} \mathrm{~A}$ plethora of specific prerequisites for integration needed to be addressed, and required a robust organisational set-up. Furthermore, procedural modi operandi for assessing progress had to be laid down in order to move through different stages of the pre-accession phase. It was clear from the start that, in addition to the state-building exercise, issues such as legal approximation, education and information, translation of the EU acquis, as well as the coordination of available pre-accession funding, had to be addressed. All of these remained equally important, as these countries were moving closer to the European Union and eventually joined in 2004 and 2007. For the pre-accession policy employed vis-à-vis Croatia, this was a point of departure. What the European Union also decided to take into account were the idiosyncrasies of the Western Balkan region. Particular attention was paid to the volatile situation in the aftermath of the war that removed Yugoslavia from the map of Europe. Indeed, geographic and historic circumstances determined that Croatia, along with other post-Yugoslav countries (joined by Albania), became part of the Stabilisation and Accession Process launched in $1999 .^{29}$

In legal terms, the main instruments of this policy are the Stabilisation and Association Agreements, the conclusion of which is subject to conditionality and benchmarking. ${ }^{30}$ These indispensable tools of the con-

\footnotetext{
27 See further on the evolution of accession criteria: C Hillion, 'The Copenhagen Criteria and their Progeny' in Hillion (n 2) 1; KE Smith, 'The Evolution and Application of EU Membership Conditionality' in Cremona (n 2) 105; M Cremona, 'Accession to the European Union: Membership Conditionality and Accession Criteria' (2001) 25 Polish Yearbook of International Law 219; K Inglis, 'EU Enlargement: Membership Conditions Applied to Future and Potential Member States' in K Inglis and Andrea Ott (eds), The Constitution for Europe and an Enlarging Union: Unity in Diversity? (Europa Law Publishing 2005).

28 See, inter alia, M Maresceau, 'Pre-accession' in Cremona (n 2) 9.

29 See, inter alia, S Blockmans, 'Consolidating the Enlargement Agenda for South Eastern Europe' in S Blockmans and S Prechal (eds), Reconciling the Deepening and Widening of the European Union (TMC Asser Press 2007) 59.

30 See, inter alia, D Phinnemore, 'Stabilisation and Association Agreements: Europe Agreements for the Western Balkans?' (2003) 8 European Foreign Affairs Review 77.
} 
temporary accession policy were, in the case of the Western Balkan countries, introduced at the very early stages of rapprochement. Croatia was no exception in this respect. The Stabilisation and Association Agreement was signed on 29 October 2001 and entered into force on 1 February $2005 .{ }^{31}$ Like other agreements of this family, it was based on two strong pillars: the creation of a free trade area and regional cooperation to ensure stabilisation in what used to be a war-torn part of Europe. The underpinning principle of the stabilisation and association process is that the progress achieved is evaluated on each country's merits. Croatia was the first country to experience this from the early days of association all the way to accession to the European Union. It should be mentioned that, unlike Europe Agreements which governed relations between the EU and Central and Eastern European countries, the Stabilisation and Association Agreements have been tailored to serve as tools for accession. ${ }^{32}$ They provided a political, economic and institutional framework that contributed to the accession negotiations, reflecting the general circumstances and goals set by both sides. ${ }^{33}$ At the same time, as part of the preparation for what became the fifth EU enlargement, the European Union developed European Partnerships and Accession Partnerships. Formally annexed to the decisions of the Council, they outlined short-term and mid-term priorities for the countries aspiring to EU membership. In the case of the Western Balkan countries, the legal basis for their adoption was Council Regulation 553/2004/EC. ${ }^{34}$ For Croatia, the European Partnership was approved in 2004. ${ }^{35}$ Following the granting of the candidate status, two Accession Partnerships followed (in $2006^{36}$ and in 2008, ${ }^{37}$ respectively). It is submitted that the usefulness of this instrument was rather doubtful, and both the European and Accession Partnerships have been quietly phased out.

\footnotetext{
31 For an academic appraisal, see S Rodin, 'Croatia' in S Blockmans and A Łazowski (eds), The European Union and Its Neighbours. A Legal Appraisal of the EU's Policies of Stabilisation, Partnership and Integration (TMC Asser Press 2006) 61.

32 K Inglis, 'The Europe Agreements Compared in the Light of their Pre-accession Reorientation (2000) 37 CML Rev 1173.

33 See the Stabilisation and Association Agreement between the European Communities and their Member States, of the one part, and the Republic of Croatia, of the other part [2005] OJ L26/3.

34 Council Regulation (EC) No 533/2004 of 22 March 2004 on the establishment of European partnerships in the framework of the stabilisation and association process [2004] OJ L86, 1-2.

35 Council Decision 2004/648/EC of 13 September 2004 on the principles, priorities and conditions contained in the European Partnership with Croatia [2004] OJ L297, 19-28.

36 Council Decision 2006/145/EC of 20 February 2006 on the principles, priorities and conditions contained in the Accession Partnership with Croatia and repealing Decision 2004/648/EC [2006] OJ L55, 30-43.

37 Council Decision 2008/119/EC of 12 February 2008 on the principles, priorities and conditions contained in the Accession Partnership with Croatia and repealing Decision 2006/145/EC [2008] OJ L42, 51-62.
} 
For Croatia, a slow move from association to membership took a slightly different turn from the fifth and sixth enlargements of the European Union. Even before the accession negotiations started in 2005, it had been clear that the rapprochement would be very much 'coloured' by the stabilisation factor. ${ }^{38}$ This, in the case of Croatia, translated into strong cooperation with the International Criminal Tribunal for the former Yugoslavia. When Croatia became a candidate for membership, the European Council invited the European Commission to prepare the negotiating framework for Croatia, taking into account the experience of the fifth enlargement, urging Croatia to 'take necessary steps for full cooperation with the ICTY' in December 2004. ${ }^{39}$ This was with the view of commencing negotiations on 17 March 2005. In the months that followed the decision of the European Council, the cooperation in question was heavily scrutinised. In particular, one high-profile case was an obstacle, that is, the indictment of General Ante Gotovina. Not satisfied with the progress made, the European Council in March 2005 decided to postpone the opening of accession negotiations. This was followed by establishing a special task force to assess Croatia's cooperation with the ICTY. Following the ICTY Prosecutor Carla del Ponte's report demonstrating Croatia's full cooperation, the green light for opening accession talks was eventually given on 5 October 2005. It should be noted that the other remaining open issue - access to government documents - did not stop the opening of accession negotiations and was eventually resolved at a later stage. ${ }^{40}$

\subsection{Lessons learned? Accession negotiations with Croatia}

\subsubsection{The basics}

A wise old saying says that one should learn from one's mistakes. Hence, as already mentioned, when preparing the negotiating framework for Croatia and Turkey, the European Union made an attempt to address the weaknesses in the fifth enlargement. The basics were laid down in the Conclusions of the European Council in December 2004. ${ }^{41}$ Even though the process was to be based on the same methodology that had been applied in the previous rounds of enlargement, it would be adjusted and tailor-made for the future Member States. ${ }^{42}$ A brief reminder is fitting that

\footnotetext{
38 See, inter alia, S Blockmans, Tough Love. The European Union's Relations with the Western Balkans (TMC Asser Press 2007).

39 See Council of European Union (2005) Brussels European Council, 16/17 December 2004, Presidency conclusions, 16238/1/04, REV 1, Conclusion 4, Brussels, 2005.

40 See further section 2.3.2 of this article.

41 Presidency Conclusions, European Council 17 December 2004, Doc No 16238/04.

42 For instance, the European Council took a decision that accession negotiations with individual candidate states will be based on a framework for negotiations. Each framework, which will be established by the Council on a proposal by the Commission, taking account of the experience of the fifth enlargement process and of the evolving acquis, will address [a
} 
at the beginning of negotiations Croatia was moving forward shoulder to shoulder with Turkey. However, the stalemate with the latter's rapprochement meant that Croatia would proceed at a much faster pace and largely on its own. In hindsight, it is clear that these two facts shaped the accession process in terms of its dynamics, the level of involvement of the relevant actors and, consequentially, the timeframe of the exercise.

An important milestone was the approval by the European Council, together with the decision on opening the negotiations, of the Negotiating Framework. ${ }^{43}$ This key policy document outlined the modus operandi to be followed: the principles, substance and procedures for accession negotiations. The main principle of the negotiations was clear: progress would be determined on Croatia's own merits and the pace would depend on Croatia's progress in meeting the requirements for membership. On the one hand, the negotiations were opened, as the benchmarks based on political criteria had been successfully met. On the other hand, the negotiating framework provided for a procedure if reforms proved to be not sustainable. Mainly, in the case of serious and persistent breaches of the principles of liberty, democracy, respect of human rights or the rule of law, the European Union was allowed to suspend the negotiations. ${ }^{44}$ The procedural mechanism is worth noting, as it served as a model for the negotiating framework with Montenegro, ${ }^{45}$ as well as with Serbia, ${ }^{46}$ and it is likely to be followed in the accession talks with other countries of the Western Balkans. ${ }^{47}$ An initiative to trigger the suspension procedure rested with the European Commission and $1 / 3$ of the Member States of the European Union. Such a request was supposed to include conditions for the resumption of negotiations. In a departure from the standard unanimity requirement applicable throughout the accession negotiations, the Council was empowered to take a decision by qualified majority. Croatia would be given the right to be heard, while the European Parliament would merely be informed. This mechanism had no legal basis in either of the Founding Treaties and its formal status was rather dubious. It

number of] elements, according to own merits and specific situations and characteristics of each candidate state'. For an appraisal, see, inter alia, Blockmans (n 29) 82-85.

43 European Council Negotiating Framework, adopted on 3 October 2005 in Luxembourg <http://ec.europa.eu/enlargement/pdf/croatia/st20004_05_hr_framedoc_en.pdf> accessed 23 November 2014.

44 Para 2 of the Negotiating Framework.

45 Conference on Accession to the European Union - Montenegro < http://ec.europa.eu/ enlargement/pdf/st20002_05_mn_framedoc_en.pdf> accessed 23 November 2014.

46 Conference on Accession to the European Union - Serbia <http://register.consilium.europa.eu $/ \mathrm{doc} / \mathrm{srv} ? \mathrm{l}=\mathrm{EN} \& \mathrm{t}=\mathrm{PDF} \& \mathrm{gc}=$ true $\& \mathrm{sc}=$ false $\& \mathrm{f}=\mathrm{AD} \% 201 \% 202014 \% 20 \mathrm{INIT}>$ accessed 23 November 2014.

47 It is based on the general negotiation framework approved by the European Council in December 2004. European Council (n 41). However, a further change of rules by the European Council cannot be excluded in the future. 
confirmed that the accession process is a Member States' driven exercise, though the threshold requirements to trigger the procedure as well as to approve the suspension decision were constructed in such a way as not to allow a single Member State or a non-representative group of Member States to suspend the negotiations without sufficient justification.

The Negotiating Framework also laid down basic requirements for the successful completion of membership talks. Quite understandably, it was a combination of the Copenhagen criteria and compliance with the Stabilisation and Association Process conditionalities. The latter included, alongside the already mentioned cooperation with the ICTY, regional cooperation as well as the peaceful resolution of border disputes. Interestingly enough, the fulfilment of obligations stemming from the main legal instrument between the two sides, that is, the Stabilisation and Association Agreement, was the last on the list. ${ }^{48}$ In terms of the substance of the actual negotiations, the Framework was based on the previous model employed vis-à-vis Central and Eastern European countries. Croatia was expected to accept the EU acquis in its entirety (including the case law of the Court of Justice), while the transitional periods would be limited to a minimum, both in terms of duration and number. Requests for transitional periods had to be properly justified and combined 'with clearly defined stages for the application of the acquis'. The Negotiating Framework provided for an important caveat: any agreed transitional arrangements could not involve amendments to rules and policies of the Union, or disrupt their functioning, or produce significant distortions of competition.

It should be noted that, as compared with the previous two enlargement rounds, the acquis was organised into a larger number of chapters. Indeed, Croatia was the first candidate to complete negotiations in 35 negotiating chapters. Some were reorganised in terms of their substance, some were merged and, more importantly, additional chapters were added. In selected areas, this move facilitated a much more detailed approach, allowing both sides to address complex issues or those that had possibly previously been undermined. This included a new Chapter 5 on Public Procurement, as well as Chapters 9, 10 and 12 (respectively, Financial Services, Information Society and Media, Food Safety, Veterinary and Phytosanitary Policy). Of highest importance was the splitting of the old Chapter 24 (cooperation in the field of Justice and Home Affairs) into Chapters 23 and 24 devoted to Judiciary and Fundamental Rights (23) and Freedom, Security and Justice (24). Combined with the political criteria, they created a platform for the scrutiny of reforms required from and pursued by Croatia.

48 Together with the European Partnership, which was subsequently transformed into a series of Accession Partnerships. See further section 2.1.3 of this article. 


\subsubsection{Three levels of conditionality}

Conditionality is present from the very start of the association and continues until the day of accession. As already noted, the Negotiating Framework for Croatia made it clear that membership was not fait accompli and membership talks could be suspended in the event of serious breaches of the benchmarks set for the opening of negotiations and of the fundamental values on which the European Union is founded. ${ }^{49}$ This meant very strict monitoring by a number of actors, including the European Commission, the EU Delegation to Croatia, as well as the Member States and other international organisations.

The most prominent and probably nationally well-known feature of conditionality is the system of benchmarking that, in the case of Croatia, was introduced almost six months after the accession negotiations had commenced. This system was introduced to measure progress in order to advance negotiations, as was made clear in the Negotiating Framework. The basic idea was fairly simple: the European Commission was empowered to set benchmarks for opening negotiations in a given chapter and then for closing it. The opening benchmarks were defined on the basis of the screening process; that is, an analytical overview of the compliance of national legislation with the EU acquis. There were 23 opening benchmarks in 11 chapters of the EU acquis, which, in general terms, focused on the necessary legal or strategic framework that should be in place to discuss further alignment. Closing benchmarks accompanied the EU common positions that were prepared for each chapter. They were formulated by the European Commission, then usually modified by the Member States in the Council Enlargement Working Group and eventually approved by the General Affairs Council. Croatia received as many as 104 closing benchmarks in 31 chapters, that is, in almost all the negotiating chapters. Closing benchmarks were more comprehensive than the opening benchmarks; the primary focus was on the implementation of Croatian legislation approximating the EU acquis. The aim was to explore if the levels of implementation were adequate. An additional novelty was the requirement to present a track record of performance. In other words, Croatia had to prove that the legislation was being implemented over a certain period of time, demonstrating concrete results or, at least, a positive trend. In each chapter, the process was completed once a final report on the fulfilment of obligations was adopted, proving that all closing benchmarks had been fulfilled and that a specific chapter was ready for provisional closure.

\footnotetext{
49 This principle was based on the general negotiation framework approved by the Euro-
} pean Council in December 2004. European Council (n 41). 
The number of benchmarks points to the fact that the European Commission recognised them as an efficient tool for guiding the process: a more thorough assessment of on-going adaptations under each chapter, as well as a stimulus for Croatia to undertake additional efforts to fulfil the requirements for EU membership. It was also considered that, as a tool, benchmarking could be used to convince the Member States that Croatia was on the right track and that a systematic approach was being applied in doing so. Therefore, the standards were clear and the efficiency of the negotiations increased. In the national context, benchmarking was initially considered as yet another obstacle and as a factor that slowed down the process of accession. Yet, rather soon, it became apparent that the benchmarking could be used to demonstrate or assure that the necessary reforms were taking place and their success was evident. Towards the end of the accession process, the results demonstrated as a part of the benchmarking exercise turned into arguments to prove that Croatia had done its 'homework' before the ratification of the Accession Treaty, and therefore no additional monitoring would be necessary after accession. They were meant to prove that Croatia was ready to undertake its obligations as a full-fledged Member State of the European Union. It should be emphasised that the benchmarking system employed vis-à-vis Croatia confirms that the pre-accession policy has become more 'tailor-made' and unique for every aspiring country.

At least three features of benchmarking merit a closer look at this stage of the analysis. To begin with, the European Commission quite heavily used sub-benchmarks within the opening and closing benchmarks. Thus, the actual number of opening benchmarks, but primarily closing benchmarks, was much higher than may appear at first sight. Under every benchmark or sub-benchmark a number of actions had to be undertaken, or documents had to be prepared. Consequently the complexity of the exercise, as well as a tight time framework, had to be addressed individually for every chapter. Furthermore, the clarity of what specific benchmarks actually required was frequently an issue. In many cases, additional consultations took place in order to define to the finest detail what exactly Croatia had to do in order to meet the requirements laid down in the benchmarks. Lastly, verification of compliance with the benchmarks was also problematic. The question was who would evaluate if a particular benchmark was complied with, and how this evaluation would be done. Was it a task of the European Commission or also of the Member States? Seemingly, this exercise was partly 'learning by doing' for both Croatia, on the one side, and the European Commission as well as the Member States, on the other.

Bearing in mind the direction in which the current pre-accession policy is going, it is worth taking a closer look at Chapter 23, which, as 
discussed later in this article, has become a centre of gravity of the accession negotiations with Montenegro and with Serbia. This is where one can see a considerable evolution of the pre-accession modus operandi. The (in)famous Chapter 23 is probably the one that the public in Croatia heard most about. Paradoxically, this happened only towards the end of the accession negotiations. The EU's strategy during the negotiations was to leave this chapter for the later stages of the membership talks. Consequently, the screening exercise in Chapter 23 was the last to be performed in October 2006. Furthermore, Chapter 23 was the last to be opened when the accession negotiations in other areas were either provisionally closed or were at least in full swing. This Chapter was eventually opened among the last ones in the negotiations (in June 2010) and due to changing circumstances it forced Croatia to present two negotiating positions in a period of one year. Not surprisingly, this chapter was the one to be closed only when the negotiations came to completion in June 2011. The main areas falling under the umbrella of the chapter in question were the judiciary, the fight against corruption, fundamental rights and EU citizens' rights. In addition, many would argue that the opening and closing benchmarks were the most complex and demanding as this chapter covers a wide range of issues. It is notable that it has a very limited, if any, EU acquis. ${ }^{50}$ It covers largely political criteria and extends to issues encompassing best international practices (for example the United Nations and Council of Europe). Overall, Croatia had to fulfil 3 opening benchmarks and 10 closing benchmarks, with a number of very detailed sub-benchmarks that were demanding both in terms of the time required for fulfilment and the substance. ${ }^{51}$ The closing benchmarks caused a lot of concerns and criticism from all sides. Firstly, receiving such a high number of benchmarks in the final moments of accession negotiations was surprising and, rather obviously, caused unease, especially since in different formats and at different levels the Croatian officials were high-

50 This, in turn, often calls for closer co-operation between the European Union and the Council of Europe. See, inter alia, D Kochenov, 'An Argument for Closer Cooperation between the European Union and the Council of Europe in the Field of EU Enlargement Regulation (2006) 2 Croatian Yearbook of European Law and Policy 311.

51 In order for Chapter 23 to be provisionally closed, Croatia had, inter alia: to update its Judicial Reform Strategy and Action Plan and ensure effective implementation; to strengthen the independence, accountability, impartiality and professionalism of the judiciary; to improve the efficiency of the judiciary; to improve the handling of domestic war crimes cases; to establish a track record of substantial results in the fight against organised crime and corruption at all levels, including high level corruption, and in vulnerable sectors such as public procurement; to establish a track record of strengthened prevention measures in the fight against corruption and conflict of interest; to strengthen the protection of minorities; and to settle outstanding refugee return issues and to improve the protection of human rights. Furthermore, Croatia had to fully cooperate with the International Criminal Tribunal for the Former Yugoslavia. See further Council of the European Union, 'Accession Conference at Ministerial level closes negotiations with Croatia' Doc No 12332/11, 30 June 2011. 
lighting that areas under Chapter 23 deserved greater attention and time for them to be addressed properly. Secondly, the 'buzz-word' of the closing benchmarks was track-record. On the one hand, it was a reasonable and sound idea to request such records as a proof of preparedness for membership. On the other hand, due to the timing and pace, it was a heavy burden for the Croatian side. The simple truth is that the basic prerequisite for a track-record is sufficient time for the tangible results of reforms. At that point, that is, when the accession negotiations were already in their sixth year, time was very much desired and its lack was rather painful. Many efforts were made to demonstrate that positive developments stemmed even from the implementation of the requirements laid down in the opening benchmarks, proving progress in reforms falling under Chapter 23. Thirdly, having in mind that the indications were that negotiations might be concluded within a year of the opening of Chapter 23, a functional coalition of Croatian $\mathrm{NGOs}^{52}$ was formed to monitor the Government's performance, pointing out issues that were not addressed properly and realising that this was the chance to insist on the implementation of reforms that might slow down once the negotiations were concluded. All these issues had an impact on both the EU and Croatian side: the continuation of the conditionality principle by the EU and the Croatian referendum on EU membership held in December 2011.

It is also worth noting that the public administration reform was not at the focus of attention from the start of negotiations. As part of the political criteria, in the initial phases of the accession negotiations, there were interventions not only from the EU but from other interested international actors. Two issues were highlighted: depolitisation as well as necessary amendments to the General Administrative Procedure Act. ${ }^{53}$ Since the developments in public administration did not exactly follow the recommendations, this issue, too, had to be addressed in the accession negotiations. Therefore, these matters were clearly reflected in the closing benchmarks starting from 2007. Strong emphasis was placed on the organisational and administrative capacities to implement Croatian legislation approximated with that of the European Union. One specific example where the lack of reform was particularly addressed was a closing benchmark in Chapter 22 (Regional Policy and Coordination of Structural Instruments). As a prerequisite for closing this chapter, there was to be a guarantee that a legal act dealing with the salaries of civil servants involved in the management of EU funds would be revised with the view to avoiding possible corruption. A solution was found in a by-law,

52 Platfoma 112 <http://gong.hr/en/active-citizens/platform-112/> accessed 30 November 2014.

53 OECD SIGMA Assessment Croatia 2011<http://www.oecd.org/site/sigma/publicationsdocuments/48970754.pdf> accessed 23 November 2014. 
while amendments to the Act on Salaries in Public Service have not been processed until today. In hindsight, the question emerges whether public administration reform was covered robustly enough during the accession process. As demonstrated below, enhancements to the pre-accession policy introduced by the European Commission in the last two years prove that more attention is being paid to public administration reform both in candidate and potential candidate countries. ${ }^{54}$

\subsubsection{Pre-accession monitoring}

Pre-accession monitoring is another aspect of conditionality that is worth paying attention to. Following completion of the accession negotiations, the centre of gravity was primarily on commitments that the European Commission considered needed additional attention and had to be fulfilled by the day of accession.

Article 36 of the Act on Conditions of Accession (which is an inherent part of the Accession Treaty) served as the legal basis for a tailor-made monitoring mechanism allowing the European Union to scrutinise how Croatia was complying with the accession commitments. This mechanism allowed the European Commission to keep its finger on the political trigger and the Council of the European Union on the 'gun' during the remainder of the pre-accession phase. The key questions were, however, how effective this mechanism would be and, if certain deficiencies in compliance with the entry conditions persisted, whether the European Union could still employ it when Croatia became a Member State. When it comes to the latter, the answer can only be an educated guess. On the one hand, Article 36 of the Act is fairly silent on that point. Unlike Articles 37-39 of the Act, which provide for the three safeguard clauses, this provision does not contain any formal timeframe. On the other hand, the existence of these safeguard clauses, combined with the standard enforcement machinery at the disposal of the European Commission (Articles 258 and 260 TFEU), made one wonder why the European Union would keep this political monitoring tool par excellence after the accession. When this article went to print, it was rather clear that this mechanism was designed mainly for the period between the signature of the Accession Treaty and its entry into force.

\footnotetext{
54 Special working groups on public administration reform are established in Albania, Serbia, FYR of Macedonia and Montenegro. For instance, in Montenegro, the special working group for public administration was established to help improve the existing framework for the implementation of the Stabilisation and Association Agreement (SAA) and its focus is solely on public administration reform <http://www.mvpei.gov.me/en/news/135349/ Press-release-Special-working-group-for-public-administration-reform.html $>$ accessed 30 November 2014.
} 
Not surprisingly, the implementation of the monitoring mechanism rested on the shoulders of the European Commission. It had the obligation to 'closely monitor all commitments undertaken by Croatia in the accession negotiations'. This covered the commitments that needed to be complied with before or by the date of accession to the European Union, including a set of JHA related commitments laid down in Annex VII to the Accession Treaty and obligations in respect of state aid to the shipbuilding industry and steel sector (Annexes VIII and IX to the Accession Treaty respectively). The tools employed in this exercise included monitoring tables as well as the regular dialogue under the SAA, peer assessment missions, the pre-accession economic programme, fiscal notifications and early warning letters to the Croatian authorities. The European Commission also had the obligation to present six-monthly assessments up to the accession on commitments undertaken by Croatia. Following the signature of the Accession Treaty in December 2011, the Monitoring Report on Croatia's accession preparations was published in April 2012. ${ }^{55}$ It was based on the Enlargement Strategy Paper and a progress report of October $2011 .{ }^{56}$ The intention was to note the progress, but also to indicate a number of areas that required improvements. In response to the recommendations made by the EU, Croatia prepared an Action Plan to address these issues. ${ }^{57}$ Of crucial importance were the findings of the Comprehensive Monitoring Report on Croatia's state of preparedness for EU membership, published in October 2012. ${ }^{58}$ In the months that followed, the European Commission focused in its monitoring, inter alia, on Chapter 8 Competition Policy, in particular state aid to shipyards that was explicitly covered by the already discussed Article 36 of the Act on Conditions of Accession. Not surprisingly, special attention was paid to Chapter 23 with the following items remaining on the radars of the European Commission: the results of the judicial reform strategy, the record in fighting corruption and organised crime, conflict of interest, antidiscrimination and ombudsman legislative acts, and Chapter 24 Justice,

\footnotetext{
55 Communication from the European Commission to the European Parliament and the Council, 'Monitoring Report on Croatia's accession preparations' COM (2012) 186 final.

56 Communication from the European Commission to the European Parliament and the Council, 'Enlargement Strategy and Main Challenges 2011-2012' COM (2011) 666 final.

57 The Action Plan for the Fulfillment of the Remaining Obligations of the Accession Negotiations was adopted at the Government session on 10 May 2012 (adopted during the closed part of the Government session, classified as limited); two revised action plans were prepared following the European Commission's Report on the State of Preparedness for EU membership in April 2012 and the Comprehensive Monitoring Report in October 2012. Reports on the implementation of the revised Action plan are available in Croatian on the Ministry of Foreign and European Affairs website <http://www.mvep.hr/hr/hrvatska-ieuropska-unija/pregovori/akcijski-planovi/> accessed 23 November 2014.

58 Communication from the European Commission to the European Parliament and the Council on the 'Main Findings of the Comprehensive Monitoring Report on Croatia's state of preparedness for EU membership' COM (2012) 601 final.
} 
Freedom and Security (outstanding issues on border management with Bosnia and Herzegovina). In less than a year before accession, there was still a list of 10 actions to be addressed and completed before the accession scheduled in the Accession Treaty for 1 July 2013. This monitoring exercise played an important role in the ratification process, when some Member States, particularly the United Kingdom, the Netherlands and Germany, were closely monitoring developments in Croatia before giving a green light to membership which materialised on 1 July 2013.

\subsection{The Croatian perspective}

\subsubsection{Introduction}

Having analysed the mechanics of the pre-accession policy that had been employed vis-à-vis Croatia, it is fitting to take a domestic perspective and delve deeper into a number of challenges this process has brought home to the Croatian authorities. In doing this, we argue that although the performance was not always flawless the Croatian state apparatus made a significant effort without which accession would not have been possible. To analyse all internal aspects of rapprochement would exceed the limits of this article. Therefore, in the paragraphs that follow, readers are presented with a snapshot of several key matters. This includes the planning of actions needed to meet the Copenhagen criteria, the coordination of Croatia's EU policy, the political consensus behind this exercise, as well as the transparency of the process. This is followed by a snapshot of the human side of this story. Arguably, without the commitment of hundreds who were involved in the process, accession would not have materialised.

\subsubsection{Timing, planning, coordination and transparency}

The four factors in the subheading above merit attention for the purposes of this analysis. As was the case during the accession negotiations with the post-communist countries, the countries aspiring for EU membership tend to predict the duration and the character of the entire process. Understandably, there is huge interest among domestic political circles concerning the completion of the accession negotiations and the EU membership that follows. In general terms, it is not advisable to make ex ante estimates of accession negotiations as to their duration and content. Optimism may overrule reality on the ground, as all too frequently such estimates neither reflect the complexity or character of the negotiations, nor take into account the idiosyncrasies of a particular country's rapprochement. The timeframe is a reflection of at least three factors: political and other circumstances in the EU Member States, the ability of the candidate's administration to respond to all the requirements placed upon it, and the capacity of the European Commission to keep 
the momentum and to assist in solving open issues in the course of the process. For instance, at the time of the Croatian accession negotiations, the economic crisis altered the level of interest among Member States and this, to an extent, removed enlargement from the priority list. Furthermore, elections to the European Parliament took place in 2009 and, as is well known, they were followed by the appointment of the new European Commission. Needless to say that from 2007 to 2009 the Member States were rather pre-occupied, first with the negotiations of the Treaty of Lisbon and, once it was signed, with the very painful road to its ratification. Against this more general political background, Croatia proceeded with its own preparations for accession.

Starting with the adoption of the Implementation Plan for the Croatian SAA, ${ }^{59}$ a lot of emphasis was placed on legal approximation and preaccession funding. It was soon clear to all that it would be a far more comprehensive exercise than initially anticipated, requiring organisational as well as administrative adjustments and reforms. The original Action Plan developed into an annual National Programme for Accession to the EU, which became a strategic governmental document, a central and essential tool for European integration and an effective instrument for defining priorities and the pace of legal approximation. ${ }^{60}$ It evolved through time from listing the SAA priority areas, through addressing the Avis ${ }^{61}$ and European/Accession Partnership priorities, to the benchmarks laid down in the accession negotiations and, eventually, the agreed results of the negotiations. As one would expect, in the period of accession negotiations an enormous number of laws and by-laws for the purpose of approximation were adopted. A peak of legislative activity was reached in 2008 when 122 laws and 334 by-laws were adopted. It is notable that since 2006 all laws and specific by-laws with approximation relevance were consulted over with the European Commission before their adoption. Another national challenge, closely related to the approximation effort, was the translation of the EU acquis into Croatian, as well as the translation of Croatian legislation into English. The former is of crucial importance and, until the day of accession, remains largely the responsibility of the aspiring country. Neglecting this technical, yet important, exercise may have, as demonstrated by the previous enlargement rounds, quite

\footnotetext{
59 Ministry for European Integration of the Republic of Croatia (2002) Implementation Plan for the Stabilisation and Association Agreement between the Republic of Croatia and the European Communities and their Member States, Zagreb <http://www.mvep.hr/hr/ hrvatska-i-europska-unija/eu-za-gradane/publikacije/publikacije-u-izdanju-mvep-a/> accessed 23 November 2014.

60 See further T Ćapeta, D Mihelin and S Rodin, 'Croatia' in A Kellermann and others (eds), The Impact of EU Accession on the Legal Orders of New EU Member State and (Pre-) Candidate Countries. Hopes and Fears (TMC Asser Press 2006) 69 and particularly 94-109.

61 Communication from the Commission, Opinion on Croatia's Application for Membership of the European Union, COM (2004) 257 final.
} 
profound consequences for the effectiveness of EU law in a new Member State after accession. ${ }^{62}$ Bearing this in mind, in the early stages of Croatia's integration process, a translation service was established for that purpose. The translation of EU legislation into Croatian started in 2003 and already in 2005 it became clear that the negotiation process would require additional efforts in translation, which would be very resource thirsty. This became even more evident in 2006 when the benchmarking system was introduced and procedural agreement was made with the European Commission. Pursuant to the latter, consultation had to take place on all draft legislation before adoption, meaning that it had to be simultaneously prepared in Croatian and English. The same applied to all documentation related to the accession negotiations, which included screening lists and presentations, negotiating positions, strategies, action plans, reports on the implementation of legislation and final reports on the fulfilment of obligations for the closing of each chapter. According to estimations, Croatia produced tens of thousands of pages in bilingual form, which was an immense workload, especially in 2007-2009, which was the most vibrant period in this respect. ${ }^{63}$ This came at a cost of approximately EUR 12 million, financed by the national budget.

Preparation for accession was a major effort. An endeavour of such magnitude and complexity goes beyond the particular interests of selected parties or governments. To put it differently, it must be a product of national consensus so that a number of reforms can be undertaken. In relation to accession negotiations, this consensus - sometimes considered as 'mission impossible' - was defined and confirmed through Parliamentary documents that provided the basis for the successful implementation of the process. Good examples were the Declaration on the Fundamental Principles of Negotiations on Full Membership of the Republic of Croatia in the EU and the Statement of the Croatian Parliament and the Government of the Republic of Croatia on Joint Actions in the Process of Negotiations on Membership of the EU (January 2005). ${ }^{64}$

Not only did those two documents encapsulate consensus over the Croatian strategic goal of becoming an EU member, they also laid down

62 M Bobek, The Binding Force of Babel: The Enforcement of EC Law Un-published in the Languages of the New Member States' (2006-07) 9 Cambridge Yearbook of European Legal Studies 43; K Lasinski-Sulecki and W Morawski, 'Late Publication of EC Law in Languages of New Member States and its Effects: Obligations on Individuals Following the Court's Judgment in Skoma-Lux' (2008) 45 CML Rev 705.

${ }^{63}$ V Drobnjak, 'Specificity of Croatia's Accession Negotiations and Implications for EU Membership' (2011) Études Européennes <www.etudes-europeennes.eu> accessed 23 November 2014.

${ }^{64}$ Croatian Parliament website <http://www.sabor.hr/Default.aspx?art=2490> and <http:/ / www.sabor.hr/Default.aspx?art=2476> accessed 23 November 2014. 
the basic principles of the (certain) transparency and openness of the process to the wider public. A forum for that purpose was established in the Croatian Parliament: the National Committee for Monitoring Accession Negotiations (hereinafter the National Committee). It was led by the leader of the opposition party, co-chaired by a ruling party representative, with members from all parliamentary parties. To ensure inclusion, it also comprised a member from the Office of the President, and representatives of trade unions, the business community and academia. The purpose of the National Committee was to discuss the open issues of negotiations, to have a consultative role in the preparation of relevant negotiating acts and to initiate further discussions with other relevant stakeholders. The National Committee was probably the easiest place to acquire information on the accession negotiations process (without the simultaneous dissemination of relevant documentation).

The transparency of the Government's work was discussed on many occasions, especially in the final phases of the accession negotiations. ${ }^{65}$ It is notable that the EU Negotiating Framework for Croatia did not contain any specific requirements for transparency, so, following a recommendation of the European Commission, neither the Government nor the National Committee presented any documentation to the public, with the intention of not jeopardising the conduct of negotiations. The Croatian Government was generally considered unwilling to share too much information. To prove this point, it is enough to check the number of points on the Government's agenda that were discussed behind closed doors. This pattern applied, too, to dossiers related to the EU accession negotiations. Such modus operandi, in turn, raised strong criticism from the public, academia and civil society organisations. ${ }^{66}$ Part of the trepidation to share more information might have been linked to insecurity about how the accession process would actually be run in the light of the rules of the game being revised by the European Commission. There was an internal reason, too. There was a degree of lack of trust in the national partners, their knowledge and will to work together for a joint cause. The situation has changed over the years. As things stand today, Croatian NGOs have managed to build a strong network with their counterparts in the region. One of the aims is passing on Croatian experience and assistance in preparing for the accession process. In more general terms, the challenges of transparency during the Croatian pre-accession phase have had a spillover effect on the levels of transparency of governmental

65 See, inter alia, I Vidačak and M Škrabalo, 'Exploring the Effects of Europeanization on the Openness of Public Administration in Croatia' (2014) 14 Croatian and Comparative Public Administration 149.

66 ibid. 
and parliamentary actions in the current candidate and potential candidate countries. That, too, has now become an important dossier in EU pre-accession policy. ${ }^{67}$

\subsubsection{People are crucial for success}

Once negotiations are in full swing, hundreds of issues are on the table in this comprehensive process. In order to meet the deadlines and keep the momentum, two aspects are essential - the knowledge of experts and properly established coordination mechanisms.

To go in depth into the details of the Croatian institutional structure for the accession negotiations would exceed the limits of this article. However, some key factors merit analysis. The institutional structures were defined by the Government in decisions on the organisational setup and appointment of members of the negotiating team before negotiations commenced. ${ }^{68}$ Just as with the National Committee discussed above, the set-up of the Negotiating Team was the result of consensus between the ruling and the strongest opposition parties. Hence, it was expected that the EU accession negotiations would have the broadest possible political support and remain a priority. The cadre of negotiators comprised mainly established professionals and well-respected experts in specific fields. Unlike the case of previous enlargements, where the majority of experts were from public administration, in the case of Croatia the team was quite diverse. For instance, one of the two Deputy Chief Negotiators, Boris Vujčić, was at that time Deputy Governor of the Croatian National Bank, while the other was the State Secretary for Strategy and EU Funds (Martina Dalić), later replaced by the State Secretary of the Ministry of Economy (Tamara Obradovic Mazal) and later the State Secretary of the Ministry of Finance responsible for pre-accession funds (Ivana Maletić). In general terms, the members of the Negotiating Team, as well as the heads of the working groups established for every chapter of the EU acquis, included state officials, representatives of academia, the Croatian National Bank, the Croatian Chamber of Commerce, Croatian employers' associations, agencies and the private sector. There were 13 negotiators whose responsibilities ranged from one to as many as four negotiating chapters. Political affiliation was never an issue, even if there were a few politically active members of the ruling or opposition

67 See, inter alia, European Commission Progress Report on Albania, SWD (2014) 304 final, $6-7,11$.

68 Odluka o imenovanju članova Državnog izaslanstva Republike Hrvatske za pregovore o pristupanju Republike Hrvatske Europskoj uniji, članova Pregovaračke skupine za vođenje pregovora o pristupanju Republike Hrvatske Europskoj uniji, voditelja Radnih skupina za pripremu pregovora po pojedinim poglavljima pregovora - pravne stečevine Europske unije, članova Ureda glavnog pregovarača i članova Tajništva Pregovaračke skupine (2005) NN 49/05 (available only in Croatian). 
parties. This was neither discussed nor misused. The Negotiating Team's various diversities were never an obstacle in its performance. Quite the contrary, the cooperation of different experts with varied profiles was beneficial, as they could complement each other in knowledge sharing, skills and consultations. The members of the working groups were even more diverse and included members of non-governmental organisations. The total number of members of all working groups varied though the process, with 1,868 members in June 2011 when the negotiations were concluded. This number should be treated with caution, though, as the levels of involvement and duration varied throughout the pre-accession phase. ${ }^{69}$ It has been estimated that there were at least 2,500 experts involved in the negotiations with varying frequency, which, considering the size of Croatia, is a serious undertaking. However, it is evident today that the large number of professionals involved has not ensured continuity in policy making upon the completion of negotiations, but rather, in many respects, it was the strong, motivated and persistent individuals that were the factor of success.

It was crucial that there was an appropriate level of understanding of the whole process, which would not have been possible without the knowledge of those deeply involved in the negotiations, their skills and, last but not least, motivation. Motivation lay not so much in financial terms, but more in the fact that this was a unique opportunity to participate in a process of such scale and transformative potential, and also knowing that it might be a sound step forward in an individual career.

Another crucial point for the process was that the majority of the core team that ran the negotiations did not change, except for those who were simultaneously appointed to positions that precluded continued involvement in the accession process (such as a judge of the Constitutional Court). This was not only the case for the chapter negotiators, but also for heads of the working groups. This stability was essential for the continuity and successful management of the process. Whenever changes did occur, it took approximately six months for the substitute to truly take over the responsibilities.

The Chief Negotiator was responsible for the direct conduct of accession negotiations. He represented Croatia at IGC meetings and held the status of ambassador, performing his duties in both an Office in the Government in Zagreb and in the Mission of Croatia in Brussels. ${ }^{70} \mathrm{He}$ was in many ways considered to be the glue of the process. In the complex web

\footnotetext{
69 Some members of the working groups were active only for a certain period of time for specific activities and inputs, while others were never included in the working groups per se, even though they were involved and provided valuable inputs and assistance (they were mostly civil servants working in public administration).

70 The same principle of division of work now applies to the Montenegrin Chief Negotiator.
} 
of coordination, the role of Chief Negotiator was important in a number of aspects. The first was the network of regular contacts with all members of the Negotiating Team. Furthermore, of crucial importance was direct contact with the Government and its ministers, the Croatian Parliament and the National Committee, as well as the close link forged with the European Commission and officials in the Member States, their permanent representations to the European Union and embassies in Zagreb. Secondly, equally important was the deep understanding of the substance of the process: Government policies and open issues deriving from the accession negotiations. The position of the Chief Negotiator in correlation with other actors and the substance of the negotiations were crucial to set the timeframe of all the activities needed to fulfil expectations, for the preparation and timely submission of relevant documentation, and to meet internal deadlines and those set by the EU side.

Coordination of the process at the national level was very complex, yet feasible. On one hand, tailor-made rules were defined by the Decision of the Government on the procedures and adoption of the negotiating positions, ${ }^{71}$ and on the other, the process fitted into the already existing rules of procedure of the Government and the Parliament. Considering that the process was constantly evolving (vide the benchmarking introduced during the negotiations) and included various stakeholders, ultimately it was beneficial that the rules were neither too strict nor too loose. This facilitated necessary pragmatism, combined with efficiency.

\section{Enhanced pre-accession policy}

\subsection{Introduction}

The underlying theme of the contemporary pre-accession policy is 'fundamentals first'. As the European Commission declared in its Enlargement Strategy 2013, the contemporary accession process is more rigorous and comprehensive..$^{72}$ This is to reflect the evolution the European Union has gone through, as well as the previous experience with the accession of the Central and Eastern European countries. The European Commission emphasised that the accession modus operandi is now based on strict conditionality and progress to the next phases of rapprochement

\footnotetext{
71 Government Decision on the procedure of preparation and adoption of the negotiating positions, 15 April 2005 and 20 April 2006; not published; available in Croatian only (Odluka Vlade Republike Hrvatske o postupku izrade i usvajanja Pregovaračkih stajališta Republike Hrvatske u pregovorima o pristupanju Republike Hrvatske Europskoj uniji (klasa: 910-04/00-03/06, urbroj: 5030109-05-30, od 15. travnja 2005. godine i urbroj: 503010906-18, od 20. travnja 2006. godine).

72 Communication from the Commission to the European Parliament and the Council, 'Enlargement Strategy and Main Challenges 2013-2014' COM (2013) 700 final.
} 
depends on the performance of the aspiring countries. The broadly defined rule of law is the centre of gravity of the pre-accession policy employed vis-à-vis the Western Balkans. Although the same principles are applied to all candidate and potential candidate countries, one major thing is noticeable: there is a great gap between the pre-negotiation stage and when the accession talks commence. On the one hand, this is understandable as countries struggling to meet the benchmarks for opening the negotiations should not be moving closer to the European Union. The presumption is that if they cannot meet the basic conditions they will not be able to comply with the far more demanding pre-accession conditionality. On the other hand, the current design of the pre-accession policy empowers the European Union with a variety of tools and instruments only once the membership talks commence. Hence, before that happens, the European Union is short of persuasive and guiding tools that are badly needed to maintain the momentum of the enlargement process and, at the same time, to make sure the results of reforms are robust and sustainable. In the paragraphs that follow, the three pillars of the contemporary pre-accession policy are scrutinised (section 3.2) as well as a new model for the accession negotiations (section 3.3).

\subsection{Three pillars of the pre-accession policy}

In October 2014 the European Commission presented its most recent Enlargement Strategy. ${ }^{73}$ It follows on from the previous annual strategic documents, although it also adds some new interesting elements. They aim at strengthening the credibility of EU enlargement and enhancing the transformative power of membership of the European Union. The process is based on three key pillars: the rule of law, economic governance and public administration reform. ${ }^{74}$ At a very general level, all three areas touch on the biggest weaknesses of the Western Balkan countries. Widespread corruption and rule of law issues remain a particular worry. The on-going economic crisis and the pains of economic transformation, combined with a volatile political environment, create a dangerous mix and fertile ground for organised crime and related phenomena. Weak public administrations are not very helpful either. Hence, the European Union is more than ever engaged in a state-creation exercise, but the question remains if it has enough instruments and powers to persuade the political circles in the Western Balkans to pursue painful reforms. The transformative power of EU accession, if it still exists, and the influence that it might still have, should be used as long as it has thrust.

\footnotetext{
73 Communication from the European Commission to the European Parliament, the Council, the European Economic and Social Committee and the Committee of the Regions, 'Enlargement Strategy and Main Challenges 2014-15' COM (2014) 700 final.

74 ibid. 4ff.
} 
In the Western Balkans, it is evident that a long pre-accession process makes it less appealing, but, at the same time, there is also the realisation that it is the only perspective for the ex-Yugoslav countries and for Albania. In the case of the pre-accession process, whatever happened in the past surely defines what will happen in the future. Knowledge of the Croatian accession process should be the most valuable and relevant one for the region - not only is it the most recent, but it could also be associated with a similar legal and administrative legacy, shared circumstances and similar challenges.

In the case of Montenegro and Serbia, for whom the accession negotiations have already commenced, the rule of law issues are the reason why the European Union decided to pursue a reversed methodology from the one previously applied vis-à-vis Croatia. It is notable that Chapters 23 and 24 have been the first to be opened. In the case of Albania, the EC in its Opinion on Albania's membership application defined 12 key priority areas that needed to be addressed (including the rule of law, anti-corruption, the fight against organised crime, human rights), which were pre-requisites for the granting of candidate status and ultimately for accession negotiations to start. ${ }^{75}$ Thanks to the progress made, that list shrank to five priorities, which, nevertheless, require major efforts. ${ }^{76}$ The European Union sponsors the High Level Dialogue allowing the governing coalition and the opposition to attempt cooperation in a political environment that is otherwise heavily polarised. In EU - Macedonia relations, the High Level Accession Dialogue has been the only development in the last 10 years, considering that candidate status was granted in 2005 and recommendations to open accession negotiations have been made annually by the European Commission but have fallen on deaf ears of the Member States. Kosovo has been subject to EULEX ${ }^{77}$ since 2009, which coordinates both structured dialogue on the rule of law and Priština - Belgrade dialogue. Finally, one should note Bosnia and Herzegovina which is stuck as a potential candidate and, alas, is engaged in very limited structured dialogue on justice and other matters.

\subsection{Enhanced pre-accession policy in practice: Montenegro and Serbia en route to the European Union}

The most relevant evidence of a 'new approach' is the current example of Montenegro, and most recently Serbia. All eyes are on the rule of

\footnotetext{
75 Commission Opinion on Albania's application for membership of the European Union, COM (2010) 680.

76 Commission Staff Working Document. Albania Progress Report 2013, SWD(2013) 414 final.

77 EULEX is the mission that supports Kosovo in the rule of law issues. See further $<\mathrm{http}: / /$ www.eulex-kosovo.eu> accessed 23 November 2014.
} 
law issues, which have translated into a new sequence of opening of negotiation chapters, as well as a more extensive and robust use of benchmarks. Indeed, these benchmarks provide even more detailed guidelines and facilitate a systematic approach to achieving results in the pursued reforms. As the then Commissioner for Enlargement and Neighbourhood Policy, Štefan Fule, said on 18 December 2013, on the occasion of the EU-Montenegro Intergovernmental Conference: "the opening of chapters 23 and 24 marks an important step in implementing the "new approach" on the rule of law issues, putting them at the heart of the enlargement process'. 78

Accession negotiations with Montenegro started in June 2012, and when this article when to print, 12 chapters had been opened and two provisionally closed. The latter were the usual suspects, Chapters 25-26 (respectively Science and Research; Education and Culture) which have hardly any EU acquis, hence there is not much substance to negotiate. When it comes to other chapters, it is notable that the screening reports have been transformed from rather general documents into more detailed instruments of the pre-accession policy. This is particularly the case in Chapters 23 and 24, where detailed benchmarks for Montenegro have been laid down. This is a very positive development, which, as argued later in this article, should be replicated in all other chapters in the case of countries where accession negotiations have not yet commenced. The first noticeable difference, in comparison to the Croatian negotiations in Chapters 23-24, is the high number of opening benchmarks - forty-five for Chapter 23 and thirty-eight for Chapter 24. Their degree of detail merits attention. For instance, in Chapter 23 Montenegro has to meet numerous benchmarks and adopt action plans when it comes, inter alia, to preventive and repressive action against corruption, the introduction of an effective legal remedy for breaches of the ECHR, implementing recommendations of the CPT, ${ }^{79}$ ensuring the protection of journalists against threats and violence, taking concrete steps to secure the implementation of anti-discrimination legislation and gender equality, taking effective steps to ensure protection of minorities, and ensuring adequate prosecution of hate crime. Equally comprehensive is a list of recommendations in Chapter 24 which ranges from asylum and immigration matters, through judicial cooperation in civil and commercial matters, to EU criminal law.

Enhanced benchmarking translates into increased effort on the Montenegrin side. To begin with, the government of Montenegro had prepared two action plans for Chapters 23 and 24, even before the accession

\footnotetext{
78 European Commission Press Release Memo, 18 December 2013 <http://europa.eu/ rapid/press-release_MEMO-13-1180_en.htm> accessed 24 November 2014.

79 European Committee for the Prevention of Torture and Inhuman and Degrading Treatment or Punishment.
} 
negotiations in these chapters were opened. Furthermore, the government prepared and adopted in December 2013 the Accession Programme of Montenegro 2014-2018. ${ }^{80}$ Those documents provide a framework for managing the process and they were prepared thanks to the mobilisation of public administration, good team work and the involvement of all relevant actors. It is notable that considering the size of the county and its administration, this comprehensive assignment is a significant burden, and so requires a group of well-motivated and skilled personnel. This is a conditio sine qua non.

In January 2014 the European Union also opened accession negotiations with Serbia. This is considered a more prominent achievement in comparison to the other countries in the region. Yet, it is also criticised for being unfair to the other countries in SEE, which have been in the accession queue for far longer. Negotiations were opened with the political support of relevant actors, following the Priština - Belgrade agreement. It is important to note that progress in that regard is written down in Chapter 35 as one of the conditions of accession. Furthermore, the Negotiation Framework puts a lot of emphasis on compliance with the rule of law benchmarks, as well as law approximation, followed by the proper implementation of the EU acquis in all the negotiating chapters. It is notable that in the case of Serbia the screening meetings for Chapters 23 and 24 had been held even before the accession negotiations began. ${ }^{81}$ This, on the one hand, allowed the EU to maintain the momentum, and on the other hand gave the Serbian authorities enough time to conduct the preparatory work. For instance, the Serbian Government prepared relevant action plans and initiated reforms. ${ }^{82}$ When this article went to print, the screening process for all chapters was in full swing with the first screening reports being made available to the public. As in the case of Montenegro, the first chapters to be opened and the last to be closed remain Chapters 23 and 24.

\section{Quo vadis? How to strengthen the pre-accession policy}

\subsection{Introduction}

The analysis of the Croatian experience presented earlier in this article proves that one of the main challenges for the countries aspiring for

\footnotetext{
80 Program pristupanja Crne Gore Europskoj uniji (2013) < http://www.gov.me> (only in Montenegrin) accessed 23 November 2014.

81 For instance, the explanatory meeting for Chapter 24 took place on 2-4 October 2013. It was followed by a bilateral meeting on 11-13 December 2013.

82 The Draft Action Plan of Chapter 23 was prepared in August 2014, and submitted to the European Commission in November 2014 <http://www.mpravde.gov.rs/files/Action\%20 Plan\%20AP23eng.1.9.pdf> accessed 30 November 2014.
} 
membership is compliance with the benchmarks set by the European Commission. This particularly applies to the contentious Chapters 23 and 24, but not only those. Arguably, this has been addressed by the recent shift in the pre-accession policy, whereby more emphasis is put on the reforms necessary to comply with EU conditionality. Changing the order in which the chapters of the acquis are opened for negotiations allows countries currently negotiating membership to build a solid track record. However, the evaluation of the pre-accession situation in Croatia also demonstrates the challenges related to law approximation, including planning, law drafting, as well as implementation of the approximated laws. The latter is particularly resource thirsty, as it requires considerable budgetary appropriations and the creation of new institutions or, in the best case scenario, considerable strengthening of existing state apparatus. Translation of the voluminous EU acquis is a major challenge, too. With relatively small and politicised public administrations in the Western Balkans, coordination of EU policy also proves to be a major hurdle on the way to accession to the European Union. While the ruleof-law related issues have gained prominence in the contemporary preaccession policy, other mundane aspects of rapprochement do not seem to attract as much attention as they arguably deserve. For this to change, the EU's enlargement policy needs to be further strengthened. In the sections that follow, several options on how to take the pre-accession policy forward are presented. The underlying theme is that the European Union needs to be more engaged in the region, not only figuratively but in real terms. Furthermore, it needs to develop new policy tools and strengthen the existing modus operandi to guarantee robust compliance with the Copenhagen criteria without, at the same time, losing the momentum. Recommendations in this respect are presented below.

\subsection{Proposals for the future}

Erwan Fouéré, in his most recent CEPS Policy Brief, has made a number of recommendations which merit attention. ${ }^{83}$ For the purposes of this analysis we will take some of them as points of departure. Fouéré rightly argues that benchmarking should be strengthened in the future. The recommendation is to employ more interim benchmarks and to adopt road maps in all policy areas. This, Fouéré claims, would allow the European Union to better assess performance in the implementation of the necessary reforms. Furthermore, strong emphasis should be placed on the actual application of national legislation harmonised with the EU acquis. Changing a law-book is relatively easy, but making new laws applicable in practice is a rather different matter. ${ }^{84}$

83 Fouéré (n 9).

84 See A Łazowski and S Blockmans, 'Between Dream and Reality: Challenges to the Legal 
In one of his recommendations, Fouéré also suggests a revision of the language traditionally employed in the European Commission progress reports. This is particularly troubling in the case of the candidate and potential candidate countries with whom the accession negotiations have not been opened yet. Progress reports remain their key policy and guidance documents. Their frequent generic style and bureaucratic jargon are fit for purpose when it comes to the politics of the accession process, but, at the same time, they make them rather unsuitable as guidance documents. ${ }^{85}$ The trouble is that assessment of the progress achieved by each country is performed by the European Commission through these annual progress reports traditionally published in the autumn. ${ }^{86}$ Anticipation of what the report will present for each SEE country is always a test for the administration in the EU aspirant country, including political circles. Traditionally, they are used for the national grading of the success of a government to deliver results for advancement in the integration process.

The question is how these concerns and recommendations can be addressed in the framework of pre-accession modus operandi. The most ambitious proposition is to open accession negotiations with the Western Balkan countries as soon as they apply for membership. In the short term, this would translate into the commencement of membership talks with Macedonia and Albania. ${ }^{87}$ As we have already noted, following several rounds of EU enlargement, the appetite for future accessions is somewhat reduced, particularly among the biggest Member States to the West of the River Elba. Hence, this scenario is rather optimistic. Yet, it could bring several efficiencies to the contemporary pre-accession policy, providing that a number of caveats are issued from the start. First, accession negotiations are no guarantee that membership can materialise. Second, accession negotiations may be suspended if a candidate under-performs. Third, the strict use of opening and interim benchmarks across the board guarantees that particular chapters of the EU acquis are opened only when the threshold conditions are met. One may argue that some, if not all, of these features are already present in the pre-accession policy, though the question is whether or not they are applied robustly enough.

Rapprochement of the Western Balkans' in P Van Elsuwege and R Petrov (eds), Legislative Approximation and Application of EU Law in the Eastern Neighbourhood of the European Union: Towards a Common Regulatory Space? (Routledge 2014) 108.

85 Fouéré (n 9) 6.

86 Progress reports are prepared based on the inputs submitted by the national administration, the Commission's own assessment as well as inputs by other relevant international institutions and the EU Member States. Methodologically, they address political and economic criteria as well as the ability to take on the obligations of membership for each country individually.

87 When this article went to print, neither Bosnia and Herzegovina nor Kosovo had applied for membership of the European Union. 
From the point of view of the effectiveness of the pre-accession policy and its catalytic effect, it is worth emphasising the importance attached, in the currently on-going negotiations, to screening reports. As the experience of Montenegro and Serbia proves, they have become a crucial instrument of the pre-accession policy. Screening reports in Chapters 23-24 set all the necessary benchmarks, and thus provide guidance for the required reforms. In other chapters, benchmarks are not so explicit, yet guidance can be deduced from the conclusions made by the European Commission. Arguably, there is no reason why detailed benchmarks could not be laid down there, too. Phasing out the European and Accession Partnerships, together with the general character of the annual progress reports, translates into a considerable mentoring and guidance gap in current relations between the European Union and candidate as well as potential candidate countries. This gap could be filled if accession talks were opened with all willing Western Balkan countries and if the screening process led to the preparation of robust screening reports with detailed benchmarks. Such an option would also have additional advantages. To begin with, it would force the aspiring countries to set up or, if they already exist, enhance the domestic modi operandi for the coordination of EU policy. The Croatian experience presented above proves how important this is for successful rapprochement. The strict benchmarks would then have to include requirements related to the functioning of public administration, including the setting-up of necessary structures for the implementation of national laws harmonised with the EU acquis. The benchmarks should be further linked to funding under the IPA Programme and serve as a point of departure at the programming stage. Last but not least, the benchmarking should also cover translation of the EU acquis into the languages of the aspiring countries. If this option were to be followed, the accession negotiations would certainly stretch in time. It is no secret that it would take the current candidate and potential candidate countries years to comply with all the requirements and build a track record that would make them, without a shadow of doubt, ready for membership. Alas, the politics of EU enlargement and the dwindling appetite for future accession among EU citizens and political circles make it a rather theoretical proposition.

This takes us to the second option, which is partly based on the same premise that further guidance and benchmarking can be provided through the screening exercise. It is submitted that the same effects as discussed above can be achieved by the separation of the screening exercise from the accession negotiations proper. To put it differently, the European Commission could be politically authorised by the Council to conduct screening and set benchmarks in all relevant chapters of the EU acquis without a formal decision to start the membership talks. A decision clearing the way for such an exercise should be easier to swallow for 
the Member States without, at the same time, opening a politically toxic debate about future enlargements. At the same time, it would allow the European Commission to proceed with conditionality and benchmarking, thus giving a badly needed thrust to the pre-accession policy. For the aspiring countries, the employment of such modus operandi would have, at least, a twofold effect. First, it would allow them to test further and to improve national coordination procedures, enhance planning of approximation, as well as build the necessary track record. Second, by bringing the negotiations closer, or at least setting a clear path to membership talks, it would allow them to maintain the necessary dynamism which, as things currently stand, is fading. Needless to say, a process based on strict conditionality and benchmarks would partly depoliticise the accession process and bring more Commission involvement into what is largely a Member States' driven exercise. This builds into Fouéré's recommendation to strengthen the benchmarking system. In terms of instruments of the pre-accession policy, they would comprise existing progress reports, serving as an annual appraisal of aspiring countries' performance, as well as detailed screening reports setting opening, interim and closing benchmarks. Some of the latter would require national measures, including detailed action plans and implementation strategies, without mentioning that they would have to be reflected in national plans for preparation for accession. In the current political climate, it would also be necessary for the European Union to continue to facilitate the dialogue between Serbia and Kosovo, as well as to continue with high level dialogues with Macedonia and Albania and political assistance provided in Bosnia and Herzegovina.

Similarly to the first option outlined above, this one would also require bold political decisions for which some Member States may not (yet) be quite ready. Therefore, a third alternative, far less politically heavyweight should be considered. Without changing the pre-accession modus operandi, it is still possible to enhance the existing policy by means of additional instruments. The diagnosis made by the European Commission in its most recent progress report outlines a number of problems for which a panacea can be found at least by two means. It is clear that benchmarking should become an inherent part of conditionality before membership talks commence. This can be achieved either by a very thorough remodelling of the annual progress reports or, as an alternative or in addition, by the adoption of mutually agreed law approximation plans. Although both would require a great deal of initiative, they are equally possible. Calls for the first are not new by any stretch of the imagination. As already argued above, their wording is rather generic and full of general phrases. To put it differently, they lack a degree of detail that would be needed if they were to serve as a guidebook for the aspiring countries. 
As far as the law approximation plans are concerned, they remain one of the options created by the Stabilisation and Association Agreements which have never been properly explored. For instance, Article 70(3) SAA EU-Albania provides that: 'Approximation will be carried out on the basis of a programme to be agreed between the Commission of the European Communities and Albania'. Furthermore, Article 70(4) SAA envisages that both sides will define the modalities for monitoring the implementation of the approximation of legislation and law enforcement actions that will be taken. Implementation of this provision as well as equivalents in other SAAs would bring a plethora of benefits. First, they would serve as guidance for the national authorities in the preparation of their national plans for the preparation for accession. Second, this would allow the European Union to set benchmarks in all chapters of the EU acquis well before the beginning of accession negotiations, screening included. Furthermore, following the SAAs, the Plans would be joint decisions of the EU and aspiring countries. This would translate, at least to some extent, into joint ownership. Obviously, the ultimate goal of this process is membership of the European Union, so candidate and potential candidate countries would eventually have to comply with the EU acquis in its entirety. This brings considerable asymmetry to the relationship, which, alas, cannot be escaped. To put such plans together, the EU would have to provide expertise, taking into account the limited capacities of public administration in the aspiring countries, as well as the lack of regulatory impact assessment and financial resources. It would be crucial to use IPA funding and financing provided by other donors to include existing and future technical assistance projects, twinning included, in such an exercise.

\section{Conclusions}

The pre-accession policy currently pursued vis-à-vis the Western Balkan candidate and potential candidate countries constitutes a further shift towards a merit based state-building process along the lines of 'more for more'. There is no doubt that the strengthened pre-accession policy based on three pillars developed by the European Union is a major and important step forward. It demonstrates that the EU has learned from the rather painful experience of the previous enlargement rounds, particularly the accession of Bulgaria and Romania. It is argued, however, that in putting the centre of gravity on the political criteria as well as on Chapters 23-24 the European Union, and particularly the European Commission, should not remove from its radar other issues that are of fundamental importance for a successful pre-accession effort. There is no doubt that it will take years for the aspiring countries to comply with all the opening, interim and closing benchmarks. It ought to be mentioned 
that since the process is dynamic, it allows the European Union and its Member States to develop tailor-made criteria that can evolve to reflect the changing legal, political and economic landscape in the countries aspiring for membership. At the same time, it remains crucial that conditionality is not used as a political tool to delay the accession of countries that perform well and meet the closing benchmarks. If that were to happen, it would seriously compromise the legitimacy of the pre-accession policy and put in doubt the pledge of a European perspective made by the European Council in Thessaloniki in 2003. ${ }^{88}$ As much as more robust political conditionality and requirements falling under Chapter 23 should be welcomed, there are a number of worrying signs that have been addressed above. Some are of a purely political nature, and some, however, touch upon mundane issues which should not slip the net. As elaborated on in section 4 of this article, far more emphasis on law approximation and implementation is required. Furthermore, the European Union needs to focus more on the institutional capacity of the aspiring countries and become even more heavily involved in the training of the judiciary. The latter was largely neglected during the 2004 and 2007 rounds of enlargement and tackled rather gently in the case of Croatia. Benchmarks are crucial to monitor the progress made by the applicants and to allow those that perform satisfactorily to progress with their rapprochement. To make better use of conditionality, it is fitting to establish the benchmarks at the very early stages of the accession process, preferably in the screening reports for all relevant chapters. Hence, as argued in this article, benchmarks should be established much earlier or, politics permitting, the accession negotiations could start sooner but be stretched in time. For the approximation effort, it would also be important to assist, including financially, the current candidate and potential candidate countries in the translation of the EU acquis. Last, IPA II funding needs to blend even further into the pre-accession policy, and priorities need to be outlined in the benchmarks. ${ }^{89}$

Summing up, the current pre-accession policy needs further strengthening. To let it go would be a mistake of immense proportions and consequences. For a variety of reasons, not only is support for further enlargements required, but it also has to be real and not figurative. This, as already argued in the introduction, is in the geopolitical interest of the EU and its Member States. Bearing this in mind, messages of support for the European perspective of the Western Balkans should

88 Council Conclusions on the Western Balkans, Doc No 10369/03 <http://www.consilium.europa.eu/ueDocs/cms_Data/docs/pressdata/en/gena/76201.pdf> accessed 23 November 2014.

89 Regulation (EU) No 231/2014 of the European Parliament and of the Council of 11 March 2014 establishing an Instrument for Pre-accession Assistance (IPA II) [2014] OJ L77, 11. 
regularly appear in the conclusions of both the European Council and the Council of the European Union. Keeping up the momentum without undermining the merits of the process should become and remain a universal mantra. The enlargement dividend is simply too great to lose. 
